\title{
Engineering geological and geotechnical site characterization for economic design of structures and earthwork
}

\author{
O O Falowo ${ }^{1}$, and W K Olabisi \\ ${ }^{1}$ Civil Engineering Department, Rufus Giwa Polytechnic, Owo, Ondo State, Nigeria \\ ${ }^{2}$ Civil Engineering Department, Rufus Giwa Polytechnic, Owo, Ondo State, Nigeria \\ E-mail: oluwanifemi.adeboye@yahoo.com
}

\begin{abstract}
The objectives of the study is to assess the engineering competence of the subsoil and develop subsoil competence map for northern parts of Ondo State, Nigeria, using integrated remote sensing, geotechnical studies, geophysical and geological investigations, static water level measurement, and borehole logging. The generated subsoil competence map was obtained by integrating the results data of these parameters measured. Consequently, the map classified the study area into moderate competence $(60 \%)$, high competence $(35 \%)$, and very high competence $(5 \%)$. The corrosivity map of the topsoil shows predominant moderate to mildly corrosivity, prominently in Ose and Akoko areas, and constitute about $70 \%$. On the basis of design, the obtained settlement values were within the $25 \mathrm{~mm}$ commonly recommended. Subsequently, areas characterized by moderate competence material can be improved by less expensive mechanical compaction and proper use of admixtures (lime, cement, bituminous addition, sand/gravel grading) to increase bearing capacity, compaction and shear strength, which will invariably reduce compressibility, settlement and permeability. Subsequently, shallow foundation such as pad or raft foundation of reinforced concrete can be adopted in the study area
\end{abstract}

\section{Introduction}

Site characterization usually provides subsurface information that assists civil engineers in the design of foundation of civil engineering structures. The primary purpose of all site investigations is to obtain the data needed for analysis and design [1]. Engineering structures are designed and constructed with long life expectancy [2] but most problems of structural failure are often associated with improper founding of foundations, poor quality of building materials, and inadequate knowledge of the physical parameters governing the competency of the soil supporting engineering structures [3]. Physical properties governing the stability of structures include but not limited to these: unit weights, porosity, consolidation, specific gravity, consistency limits of the soil in association in water, bearing capacity, shear strength, compaction characteristics, etc. Also these properties depend on the nature of soil or rock in terms of mineralogical contents, texture, and geologic structures. Therefore for engineering site investigation to be effective, it must employs an integrated method. Since engineering site investigation should be multidisciplinary in approach, if it is to be effective. It should involve geomorphological, geological, groundwater studies, remote sensing, geophysical investigation, geotechnical investigation/analysis, and borehole logging (to control the geophysical interpretation). Therefore many aforementioned workers failed in one or the other to use integrated approach, especially where geophysical methods were used. Many failed to constrain the interpretation of their geophysical results with borehole logging. Also, many couldn't map the water table and flow direction. 
All these information gap in the previous works were considered in this study by integrating all these methods to evaluate and characterized the northern part of Ondo State into different into different engineering subsoil competence zones, for construction purposes and building development. The findings of the study would aid the structural engineer and builders in the design of appropriate structures and earthwork that command professional feat.

\subsection{Description of the Study Area}

The study area is located within the northern part of Ondo State, Nigeria (Figure 1). The selected areas include Owo, Akoko, and Ose. These areas are located within longitudes $5^{\circ} 20^{\prime} \mathrm{E}$ and $6^{\circ} 10^{\prime} \mathrm{E}$ and latitudes $6^{\circ} 30^{\prime} \mathrm{N}$ and $7^{\circ} 40^{\prime} \mathrm{N}$. The area is accessible through the Benin - Ifon highway, Abuja - Lokoja Highway and Ado-Akure Highway. The study area has a topographical elevation varying from $40-$ $750 \mathrm{~m}$ above the sea level. The northern part of the study area is a rugged terrain (i.e. hilly) especially in Akoko area [4], (Figure 2). The lowlands are widespread at Ute and Okeluse axes of the area with gentle slope, while the gradient of the northern areas are generally steep. Another aspect of the relief of the area is the prevalence of many erosion gullies along hill slopes (Figure 3). The gullies are very common and rather devastating in Owo, Ifon, Ikare, Oke Agbe and Isua.

The mean annual temperature is between $21^{\circ} \mathrm{C}$ and $33^{\circ} \mathrm{C}$ (Figure $4 \mathrm{a}$ and b) with mean temperature of $24^{\circ} \mathrm{C}$ and mean humidity of $80 \%$. The mean temperature is highest at the end of the Harmattan (averaging $28^{\circ} \mathrm{C}$ ), that is from the middle of January to the onset of the rains at the middle of March. The area is situated within the tropical rain forest region, with a climate characterized by dry and wet seasons. According to Federal Meteorological Survey [5] the annual rainfall ranges between 1000 and $1800 \mathrm{~mm}$, with a mean annual rainfall of $1500 \mathrm{~mm}$ (Figure 4c). The vegetation is the rainforest type and is composed of teak, Melina/pulp wood (Figure 1), tall crowned trees mixed with thick undergrowth and of woody savannah. The vegetation is of distinct arrangement with tall trees of about $60 \mathrm{~m}$ in height, with smaller herbaceous plants found below them.

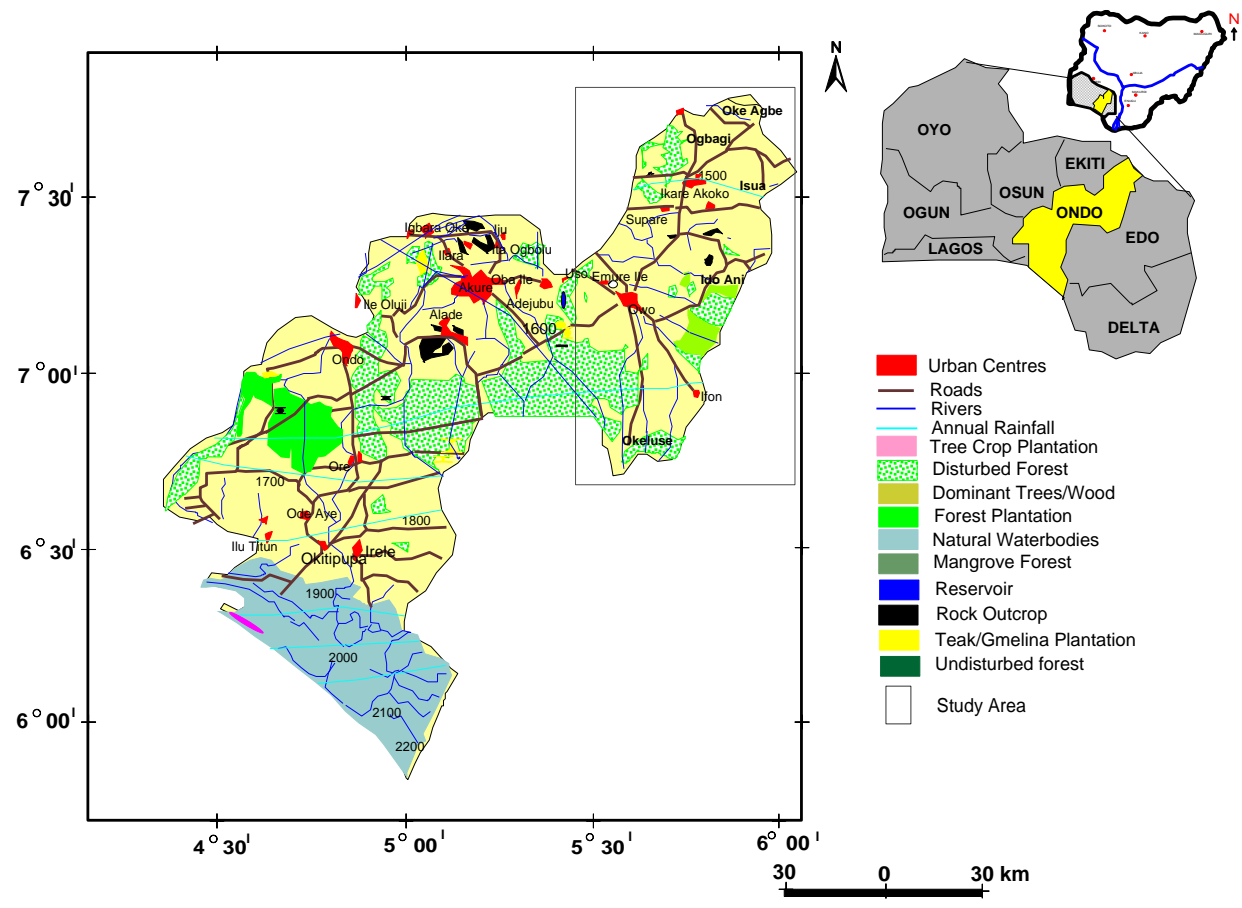

Figure 1. Land Use Map of the Study Area showing predominant Teak/Gmelina Plantation and Disturbed Forest. Inset: Location of Ondo State on Nigeria Map [9] 


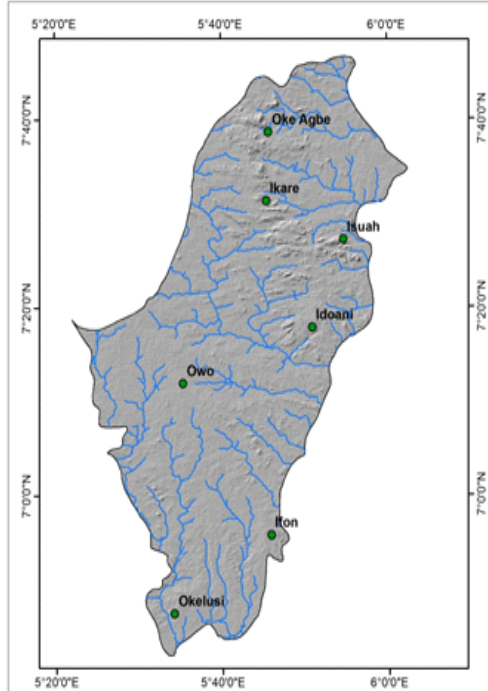

(a)
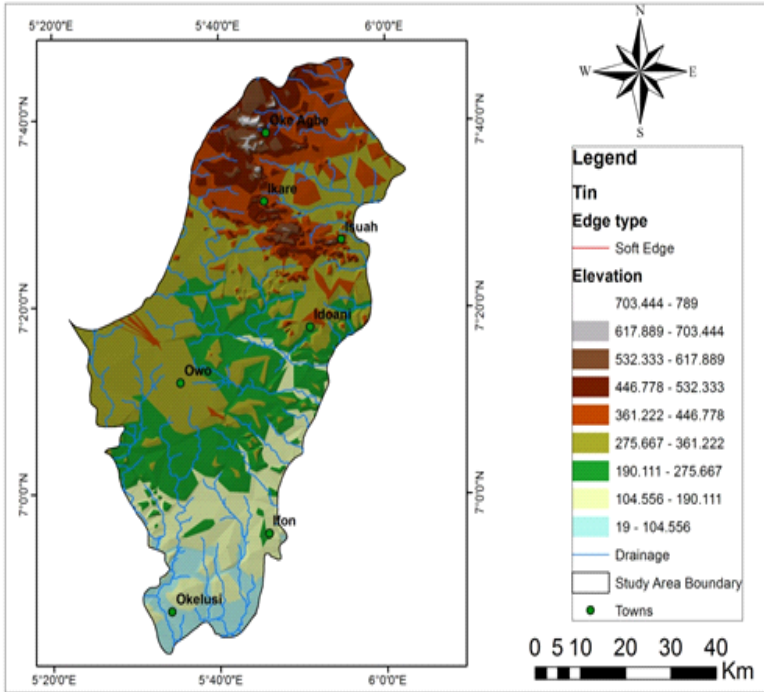

(b)

Figure 2. Topographical Elevation of the study area (a) Hill Shaded obtained from ASTER DEM data

(b) Triangular irregular Network

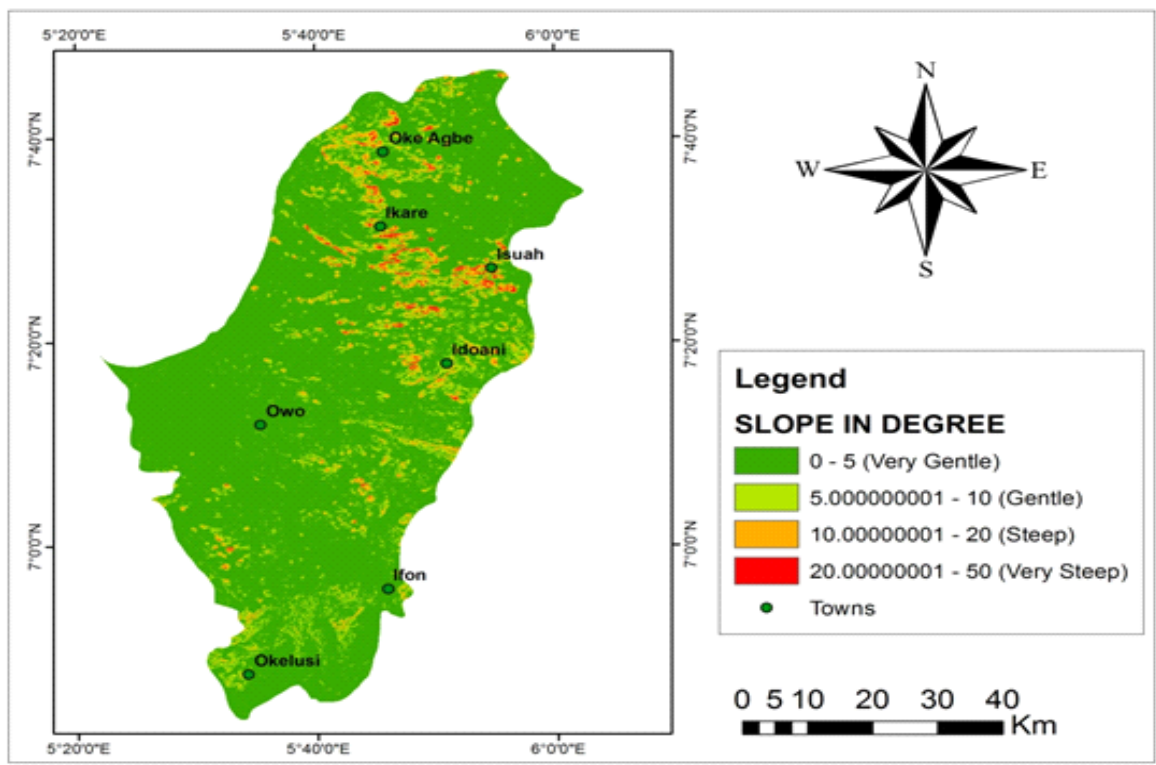

Figure 3. Slope Map of the Study area with northern areas showing very steep gradient, while Owo and Ose are predominantly gentle slope

1.2. Geology and Hydrogeology

The Precambrian Basement rocks of Nigeria include the Migmatized gneissic complex (MGC) of Achaean to early Proterozoic age [6], N-S trending Schist Belts of Upper Proterozoic age [7] and the Older Granitoid of Pan African age. The geology of study area falls within the southwestern basement complex (Figure 5a) and consists of migmatite, granite gneiss, fine grained quartzite, pegmatite and quartzo-feldspathic veins, schist, and quartz schist. These rock types dominate Owo and Akoko areas, notably along Owo - Oba Akoko, Iwaro - Akungba, Akungba - Supare, Ikare, Epinmi, Sosan, Oke Agbe, and Ido Ani. 


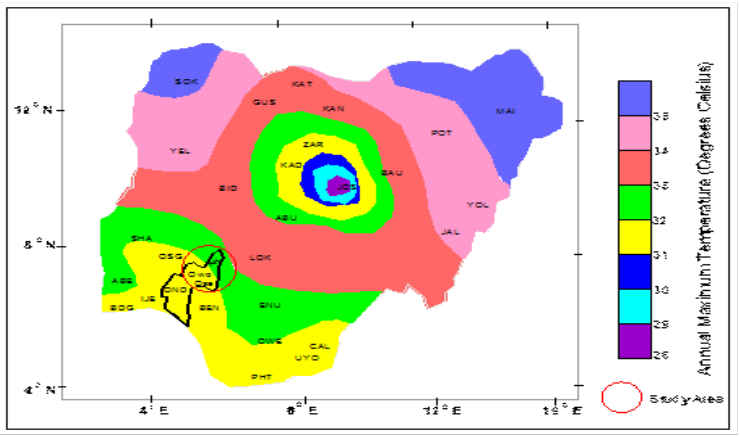

(a)

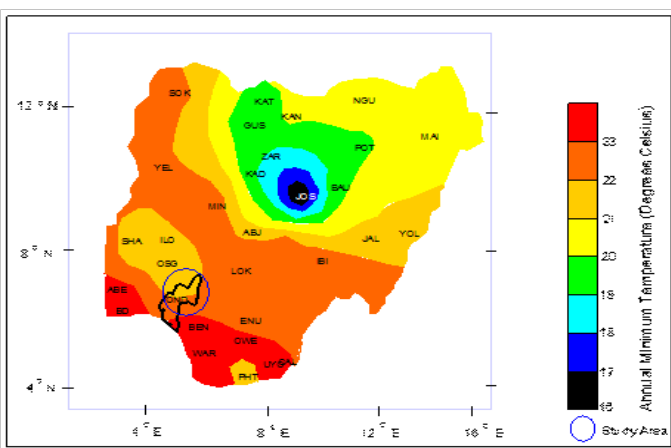

(b)

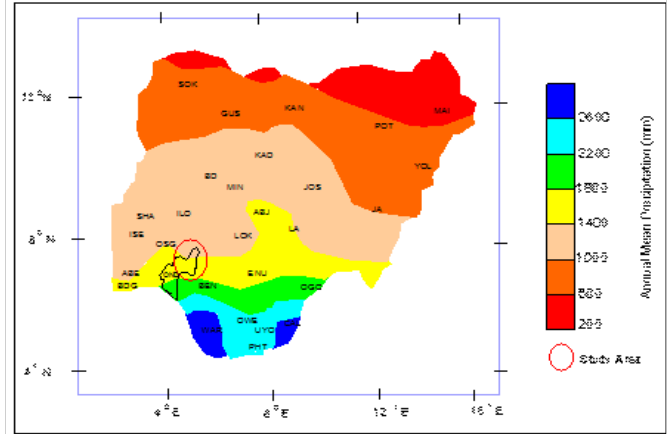

(c)

Figure 4. (a) Annual minimum temperature across Nigeria showing a range of $20-23{ }^{\circ} \mathrm{C}$ in the study area (b) Annual maximum temperature ranging from $31-33{ }^{\circ} \mathrm{C}$ (c) Annual mean precipitation across Nigeria with a range of $1000-1800 \mathrm{~mm}$ in the study area

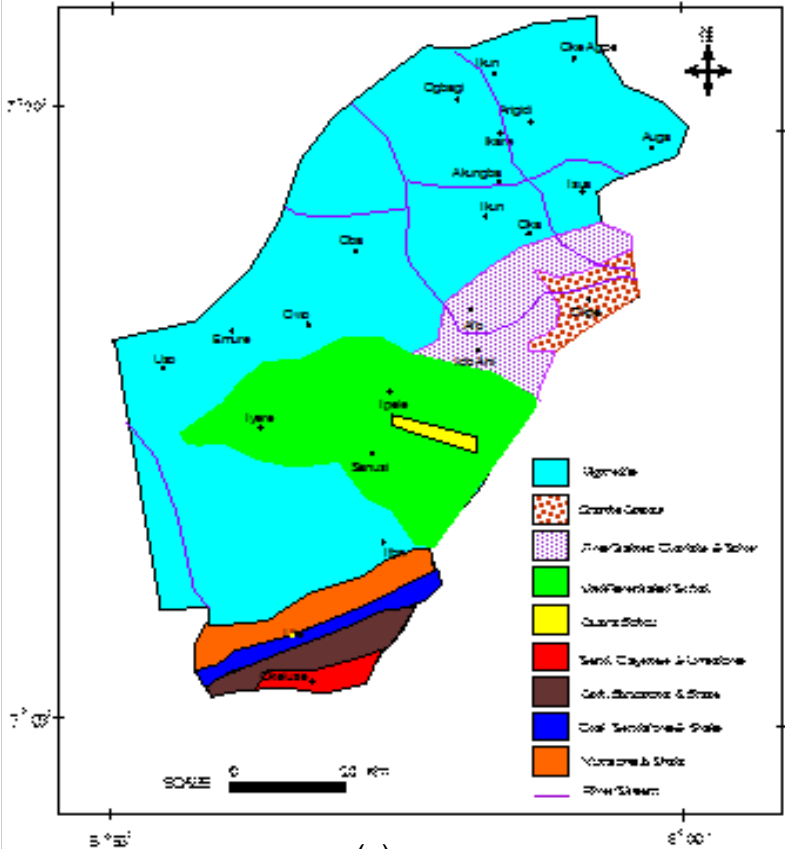

(a)

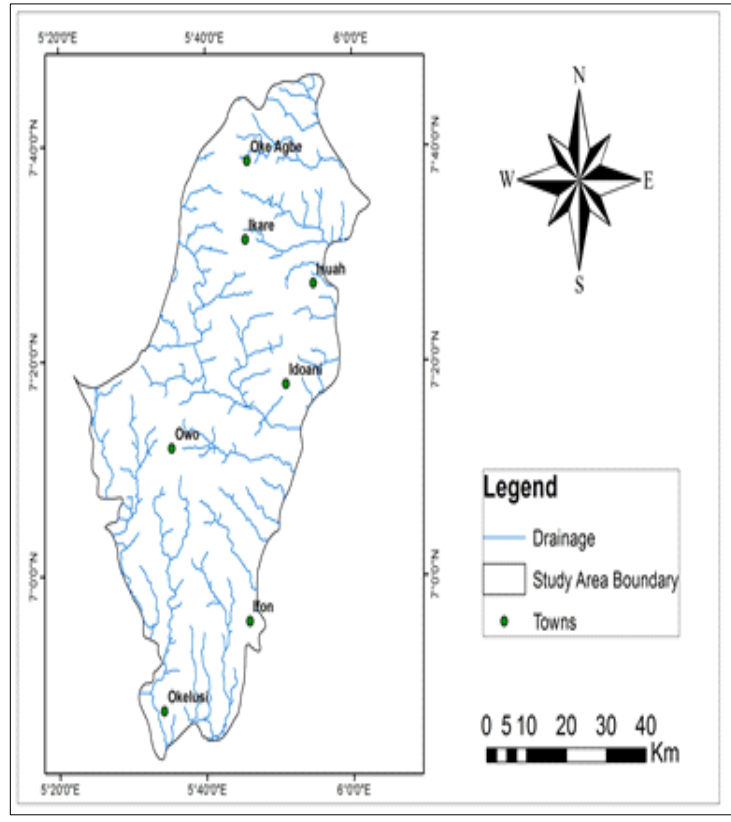

(b)

Figure 5. Local Geology Map of the Study Area with the Basement rocks occupying 90\% of the area, while the sedimentary rocks/deposits occupy a little portion of the southern area [10] (b) Drainage Map of the Study area showing a predominantly Dendritic Drainage Patterns 
The migmatite complex which is the most widespread basement rock in the area is mainly medium grained gneiss. They are strongly foliated rocks frequently occurring as outcrops. On the surface of these outcrops, severely contorted, alternating bands of dark and light coloured minerals can be seen. These bands of light coloured minerals are essentially feldspar and quartz, while the dark coloured bands contain abundant biotite. A small proportion of the area especially to the northeast, overlies the coarse grained granites and gneisses, which are poor in ferromagnesian minerals. These rocks are covered by regoliths with thickness variation across the town.

The sedimentary rocks/deposit is mainly of the post Cretaceous sediments and the Cretaceous Abeokuta Formation. The major surface waters in the study area are rivers Ogbese, and Ose (Figure $5 b$ ). Others are the small tributaries joining the major rivers (Figure 5b). The volume of water in the streams depends on the seasons. During the raining season, there is a great increase in water flow volume in the major rivers while there is hardly water in some of the streams during the dry season. Therefore rainfall is the dominant factor that determines the occurrence of groundwater.

\subsection{Soil}

The soils derived from the Basement complex rocks are mostly well drained, with a medium texture [8]. The major soil associations in the study area are Iwo, Ondo, and Okemesi (Figure 6). The soil, classified as Iwo Association, is the most prominent soil type. All the soil associations are well drained.

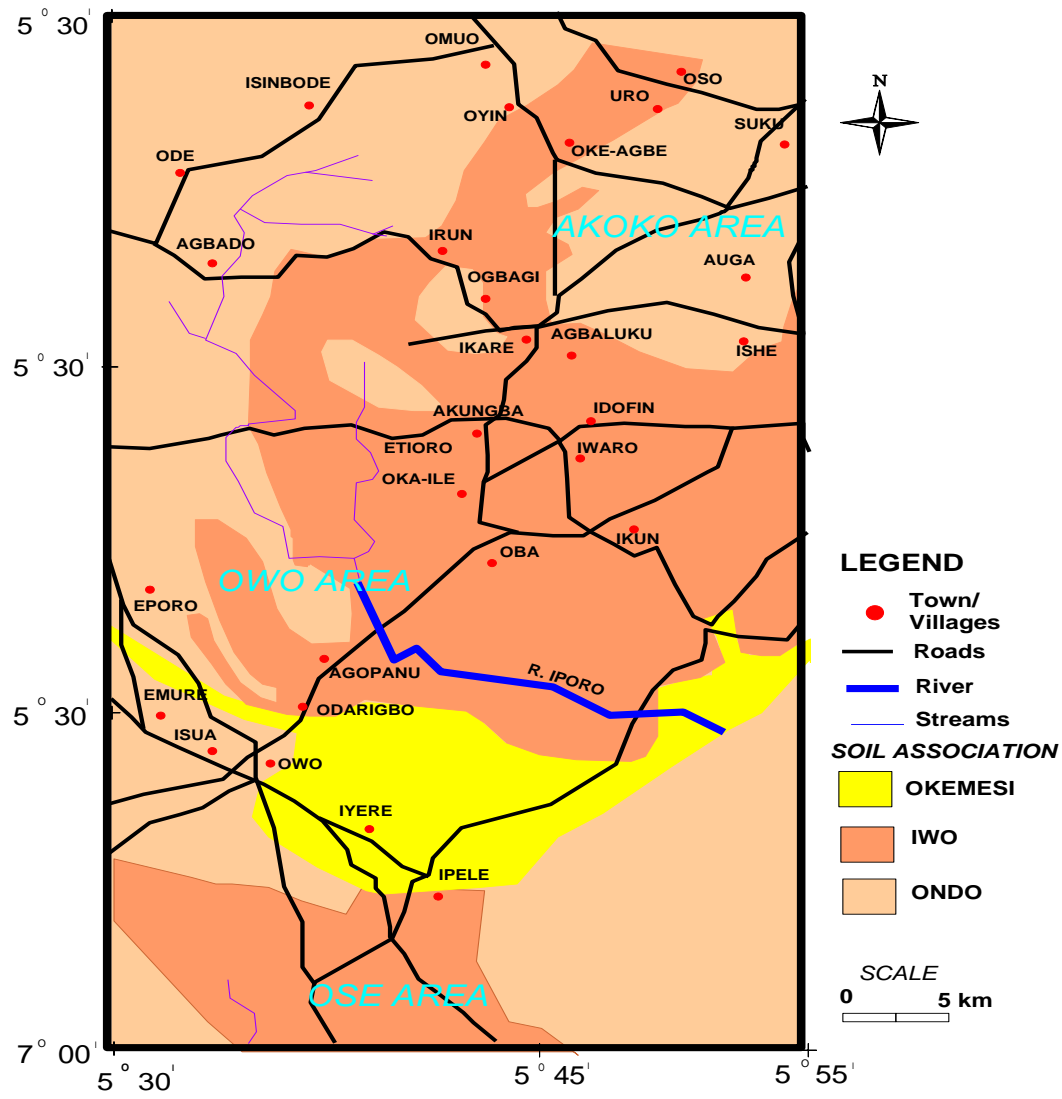

Figure 6. Soil Map of the Study Area (Extracted from [8]) 


\section{Material and Methods}

The investigation involved exploration and sampling of soil likely to be significantly affected by structural loads. The research work entailed:

\subsection{Literature Review}

The research work involved literature review of texts, technical journals, various articles, past projects thesis etc., as related to the uses of geotechnical, remote sensing, and geophysics as tools in engineering site investigation and groundwater studies. Existing Landsat-7 ETM ${ }^{+}$satellite imageries were used for the production of lineament map of the study area.

\subsection{Reconnaissance Studies and Desk Study}

The purpose of the site reconnaissance is to confirm and obtain additional information from the site. This includes taking notes of the geologic and topographic setting of the area, taking of photography of the site. Personal interview were made with residents of the area with the relevant information which will assist in carrying out the research successfully. Also sample points locations for geotechnical investigation were marked and pegged respectively. The desk study included reviewing/updating and reconciling the information obtained during the reconnaissance study and those obtained during review of journals and various articles. Subsequently the following information was reviewed:

i. Geological Maps/Report: The geological map/report together with an understanding mode of origin of the rocks and the associated depositional process enabled a preliminary assessment of ground condition.

ii. Topographical Map: The topographical map was used to examine the terrain, access and site condition. The topographic map was confirmed through site reconnaissance.

iii. Site Histories and Details of Adjacent Development: Also important information such as land use before the current development and underground services (like buried pipes and utilities) were acquired before the planning and conduct of the field test.

\subsection{Geophysical Investigation}

The geophysical investigation involving electrical resistivity (Vertical Electrical Sounding (VES) and Dipole-Dipole profiling); Very Low Frequency Electromagnetic (VLF-EM) were carried out along thirty six traverses (Figure 7). The geographic co-ordinates of data stations were taken using GARMIN'S GPS 12 - Channel model. One hundred and three (103) sounding stations were occupied with current electrode spacing varied from 1 to $225 \mathrm{~m}$.

\subsection{Geotechnical Investigation}

Twenty four soil samples were taken according to the geology/rock units in the area (at a depth less than $3 \mathrm{~m}$ ) from borough pits (Figure 7). These samples were subjected to grain size analysis, specific gravity determination; natural moisture content test, consistency limit test, compaction test, cone penetrometer test, undrained triaxial test, shear strength and bearing capacity were determined.

\subsection{Hydro-geological Measurement}

This includes determination of hydraulic head of wells/borehole and measurement of static water levels from three hundred and two (302) water wells using water level meter recorder (Figure 7).

\subsection{Data Analysis and Interpretation}

The geophysical data were interpreted qualitatively and quantitatively, as related to the objectives of the study. Profiles, maps, geoelectric section, graphs, chart were produced from the interpretation of both geophysical, geotechnical, and hydrogeological data. 


\section{Results and Discussion}

\subsection{Lineament Analysis}

Some of the lineaments mapped are joints and faults. Other linear features are suspected to be fracture and fissure zones. As shown by the lineament map (Figure 8) four major structural trends that are typical of the Nigerian basement complex are all represented in this area. These include the NE - SW, $\mathrm{NW}-\mathrm{SE}, \mathrm{N}-\mathrm{S}$ and $\mathrm{E}-\mathrm{W}$ trends (Figure 8 ). The predominant structural trend is NE - SW. The lineament map shows a wide spatial variation as the lineaments are generally sparse in the southern areas (Ifon - Okeluse), and high in Akoko area, especially around Oba, Isua, Ogbagi, Ikun and Irun. The denser lineaments area typified the intensity of rock fracturing, which is a prerequisite for development of hollow passages over an area. According to [11] the zones of relatively high lineament density are identified as zones of high degree of rock fracturing, which are prerequisite for groundwater conduit development which might be inimical to foundation structures especially when they occur at shallow depth. The lineament intersection provides interpretation of hidden subsurface tectonic configuration in the form of linear feature intersection / cross cutting geological structures, which are indicators of deep seated fracture / fault medium. Figure 8a shows that the areas underlain by high density are characterized by relatively high lineament intersection. The zones of high lineament intersection over the study must be seriously taken into consideration during the design process of structures and utilities in study area, especially areas where the rock outcrops.

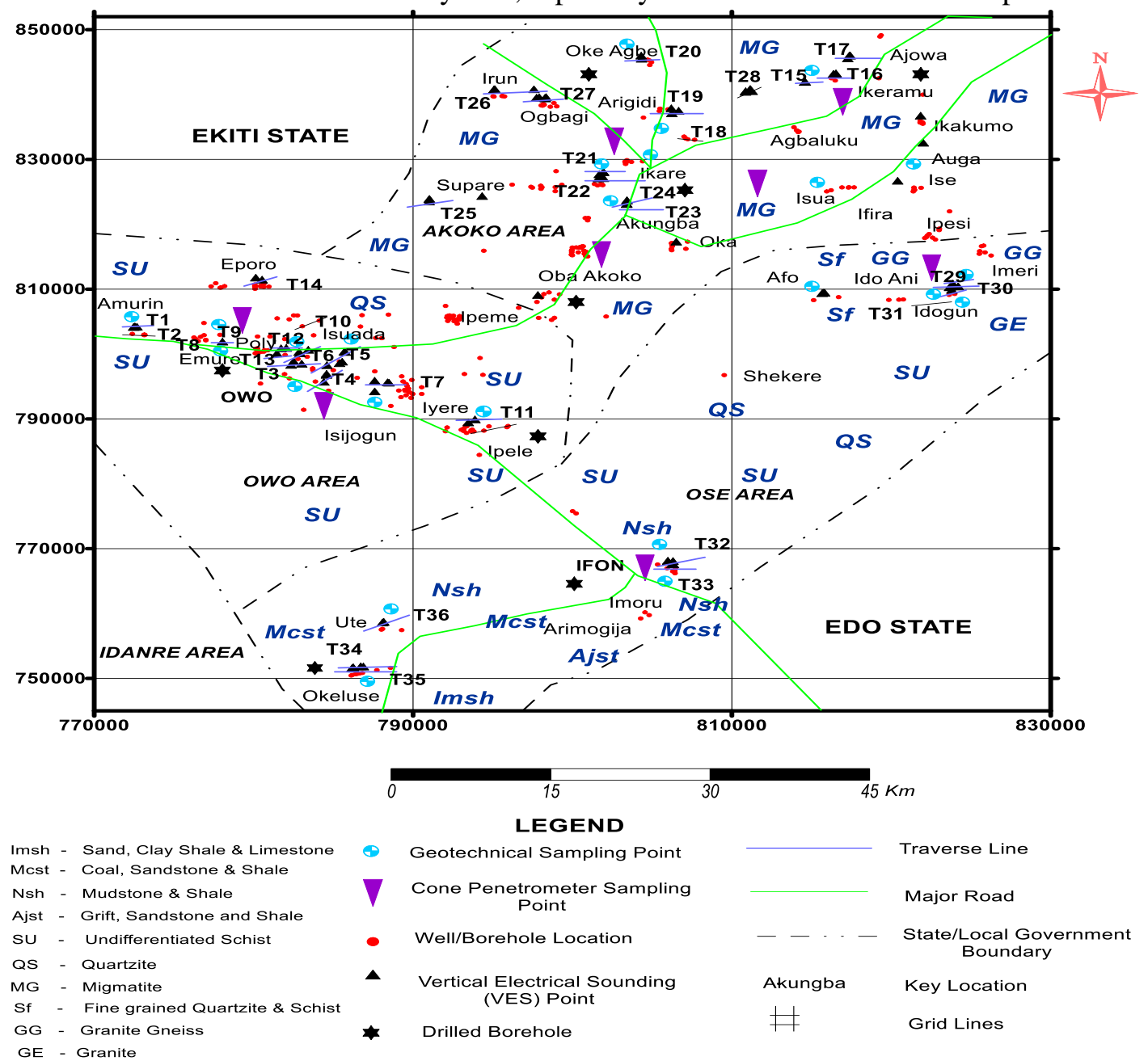

Figure 7. Data Acquisition Map of Study Area showing the Vertical Electrical Sounding Stations, Borehole Points, and Geotechnical Sampling Points 


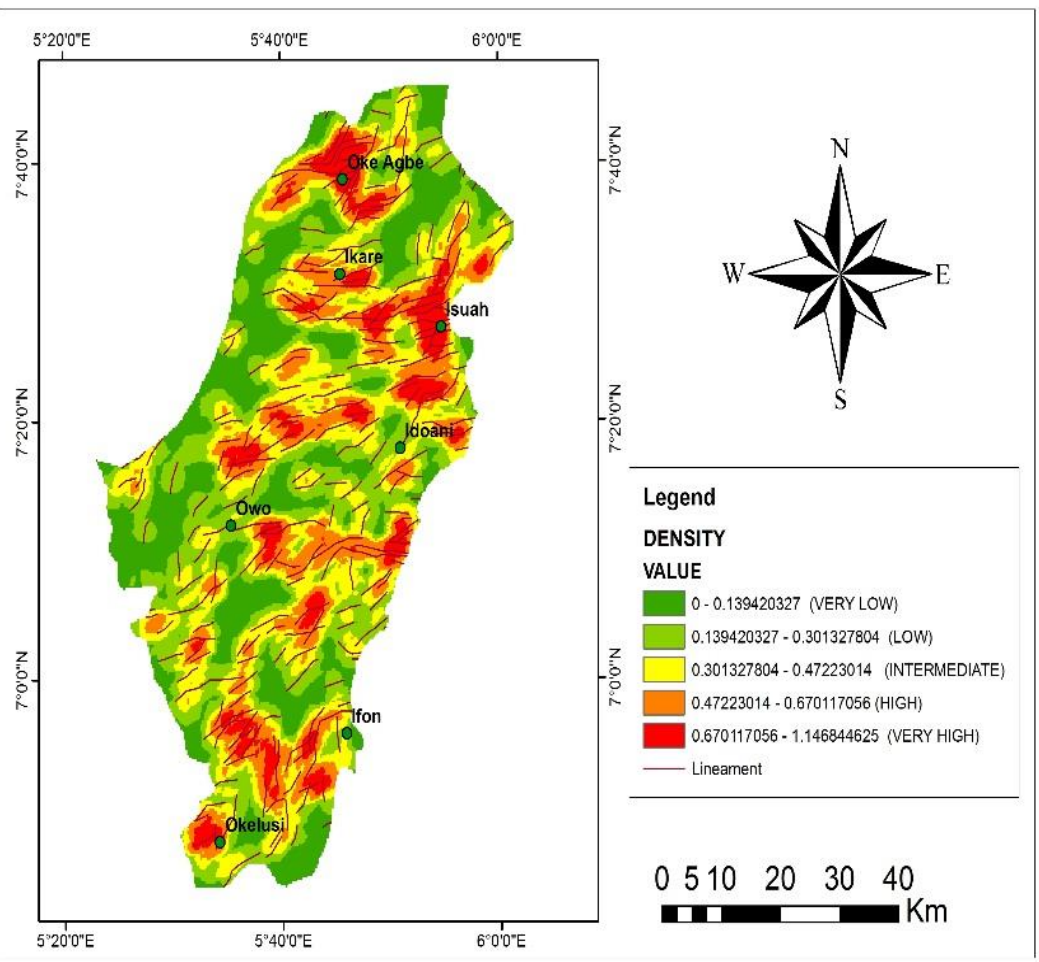

(a)

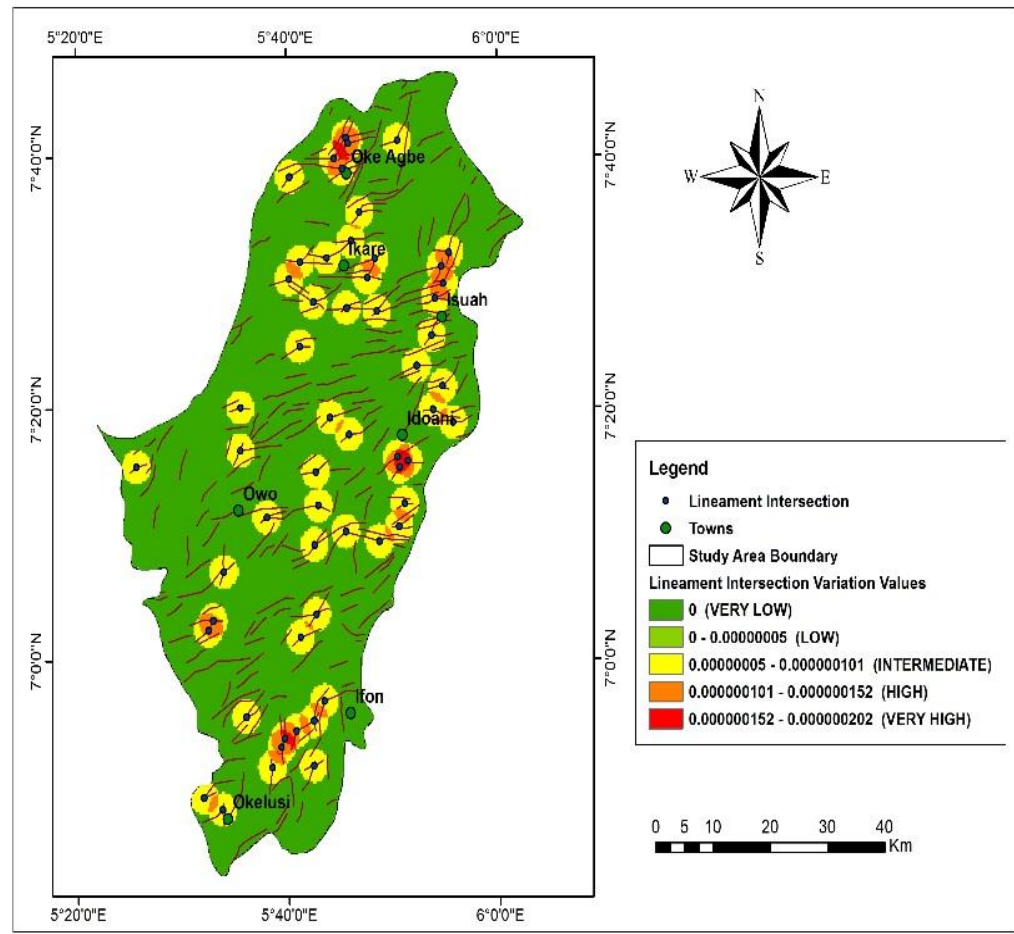

(b)

Figure 8. (a) Lineament Density map (b) Lineament Interception map generated for the study 


\subsection{Geophysical Investigation}

Table 1 gives a summary of the results of the VES curves obtained from the study area. The number of layers varies between three (3) layers and six (6) layers. Ten curve types have been identified: A, H, HA, HK, KQ, KH, QH, HKH, KHK and KHKH (Figure 9) The most occurring curve types identified are H, HA, and KH. Typical curve types are shown in Figure 10. These type curves can be classified into four distinct classes in relation to their engineering competence (table 2) by using their interpreted resistivity and thickness values as Class $1,2,3$, and 4 and are rated very good, good, moderate, and fair respectively. A-curve type is rated "very good" and widely found in Akoko area; KH, KHK, $\mathrm{KHKH}$, and KQ are rated "good"; HK and HKH are rated "moderate"; and H, HA, and QH are rated "fair".

Table 1. Curve Types and their Statistical Frequency obtained from the Study Area

\begin{tabular}{llllllllllll}
\hline $\begin{array}{l}\text { Location/Curve } \\
\text { Type }\end{array}$ & HKH & H & HA & HK & KHKH & KQ & KH & A & KHK & QH & $\begin{array}{l}\text { Total No. } \\
\text { of VES } \\
\text { Curves }\end{array}$ \\
\hline Owo Area & 2 & 15 & 2 & 4 & 3 & 1 & 6 & 2 & - & - & 35 \\
Akoko Area & - & 25 & 9 & - & - & - & 1 & 8 & - & - & 43 \\
Ose Area & 3 & 5 & 5 & - & - & 1 & 8 & - & 1 & 2 & 25 \\
Frequency (unit) & 5 & 45 & 16 & 4 & 3 & 2 & 15 & 10 & 1 & 2 & - \\
Frequency (\%) & 4.8 & 43.6 & 15.5 & 3.8 & 2.9 & 1.9 & 14.5 & 9.7 & 0.9 & 1.9 & - \\
\hline
\end{tabular}

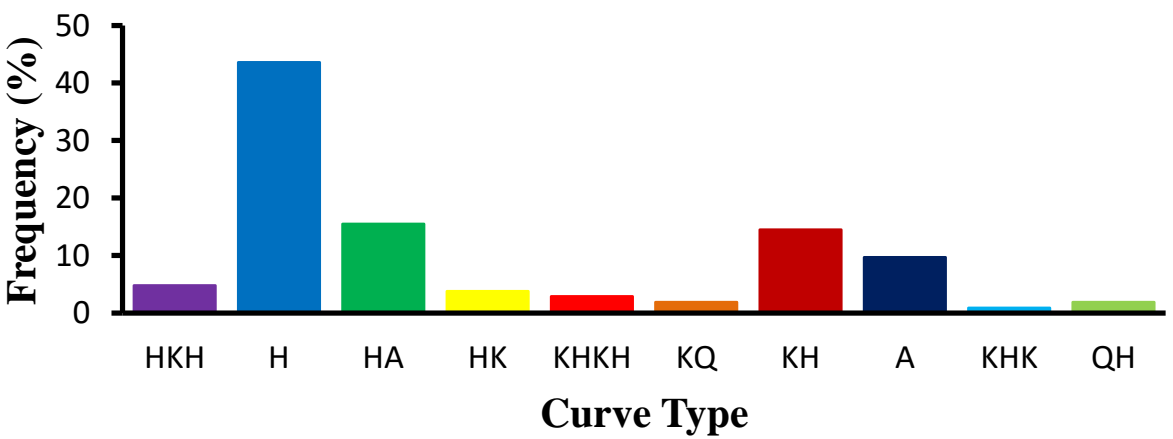

Figure 9. Curve Types obtained in the Study Area with a predominant H-Curve

\subsection{Geo-electrical Maps}

The topsoil competence and corrosivity map of the uppermost $5 \mathrm{~m}$ and depth to basement rock over the study area are presented in Figures 11-13 respectively. The topsoil constitutes the layer within which normal engineering foundation is founded especially in the basement complex [12] and can be qualitatively evaluated from layer resistivity and the geotechnical parameter. Figure 11 shows a predominant moderate competence in Okeluse, Elegbeka, Amurin, Owo, Ipele, Ido Ani, Imeri, and about constitutes about $60 \%$ of Akoko area. The moderate competent soil account for $70 \%$ of topsoil with resistivity between $100 \Omega-\mathrm{m}$ and $350 \Omega-\mathrm{m}$. Areas that show incompetency include Ikun, Oba, and Aiyegunle and account for $15 \%$ with resistivity less than $100 \Omega$-m. High competent areas are observed in Isijogun, Arigidi, Ehinogbe, Agbaluku and Ajowa These areas are underlain by quartzite, granite, granite gneiss and gneiss, and account for about $15 \%$. Therefore civil engineering foundation structure can be carried out in the study area without any failure expectation (on the basis of resistivity values obtained), while Ikun, Aiyegunle, and Oba can be graded or stabilized with more competent soil like laterite, sand or gravel to increase their density, compaction, and bearing capacity. 

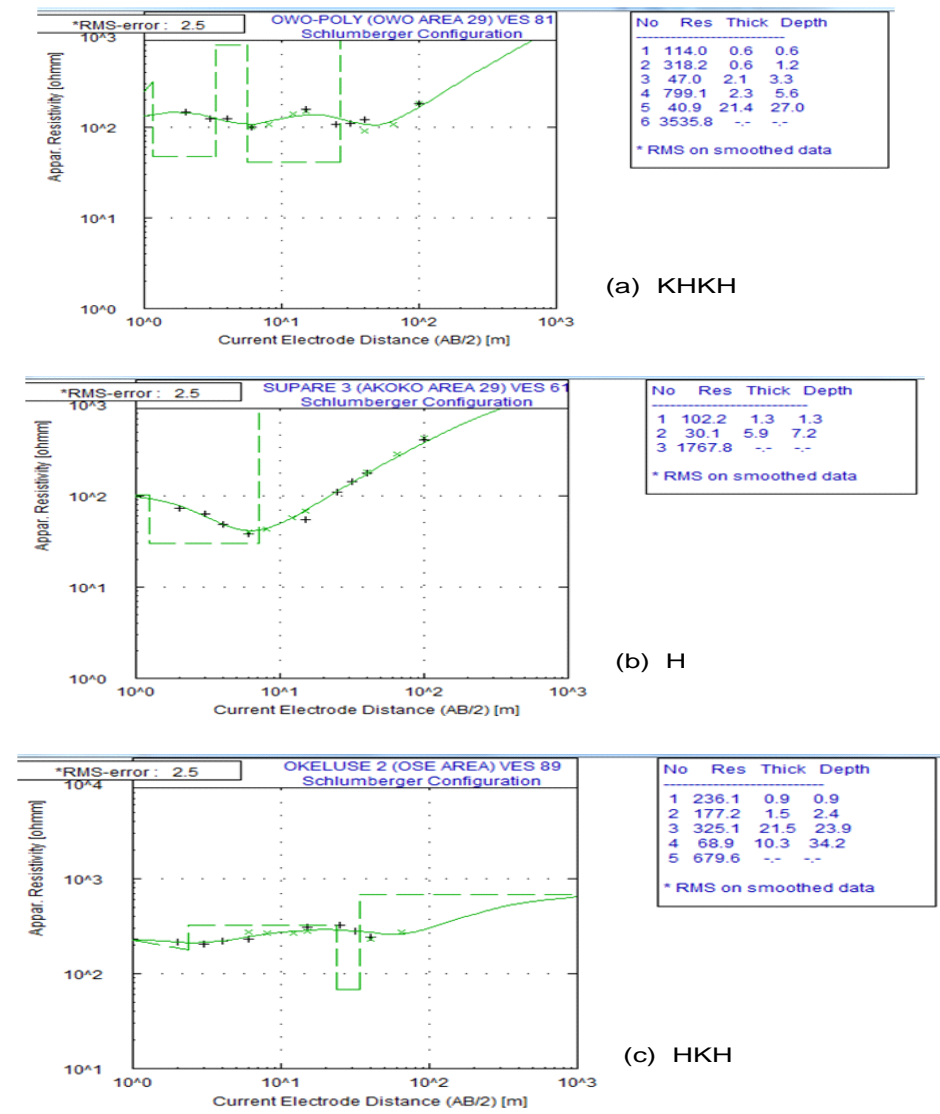

Figure 10. Typical Curve Types obtained in the Study Area

The corrosivity map of the topsoil shows predominant moderate to mildly corrosivity and very prominently in Ose and Akoko areas, and constitute about $70 \%$. The essentially non-corrosive areas which account for $10 \%$ are observed in Ajowa, Agbaluku, Ehinogbe, and Isijogun. However, the corrosivity of the subsoil in the study area shows that Akoko area are essentially non-corrosive except few places like Oba, Ikun, Ipesi, some part of Irun. Owo area and Ose are moderately/mildly corrosive. Figure 13 shows the overburden thickness/depth to basement rock across the study area. It shows that Akoko area (except Oke Agbe, Agbaluku, and part of Ikare) are generally characterized by thin overburden thickness less than $10 \mathrm{~m}$, and signifies shallow depth to basement rock and low depth of weathering; while Owo and Ose have thick overburden thickness ranging from $10 \mathrm{~m}$ to $50 \mathrm{~m}$.

\subsection{Hydrogeological Measurement}

A good set of reliable groundwater level measurements is the best foundation on which to build an understanding of a groundwater system. Groundwater conditions play an important part in the stability of foundations. If the water table lies very close to the base of footings, the bearing capacity and settlement characteristics of the soil would be affected. The water level in the well represents the water table or phreatic surface. Static water level refers to the level of water in a well or borehole under normal, undisturbed, no- pumping conditions. The hydraulic head obtained in the area were used to determine the groundwater flow direction as presented in Figure 14. Static water level measured in Owo varies from $1.2 \mathrm{~m}$ to $14.7 \mathrm{~m}$ with an average of $6.5 \mathrm{~m}$. In Akoko area it ranges between $0.8 \mathrm{~m}$ and 15.2 with an average of $1.8 \mathrm{~m}$; while in Ose area it is between $3.1-15.9 \mathrm{~m}$ and an average of 10 $\mathrm{m}$. The hydraulic head recorded in Ose and Owo ranges between $40 \mathrm{~m}$ (Okeluse) - $390 \mathrm{~m}$ (Ido Ani) and 240 to $390 \mathrm{~m}$ respectively. Akoko area is varies between 290 and $540 \mathrm{~m}$ (Irun, Arigidi, Oke 
Agbe). The general groundwater flow direction is south. Consequently, the SWL in the northern areas are very high indicating a likelihood of high water levels during the rainy season (which could even lead to spring condition), that may affect basement/foundation footings, and subsequently compromise the integrity of such structures.

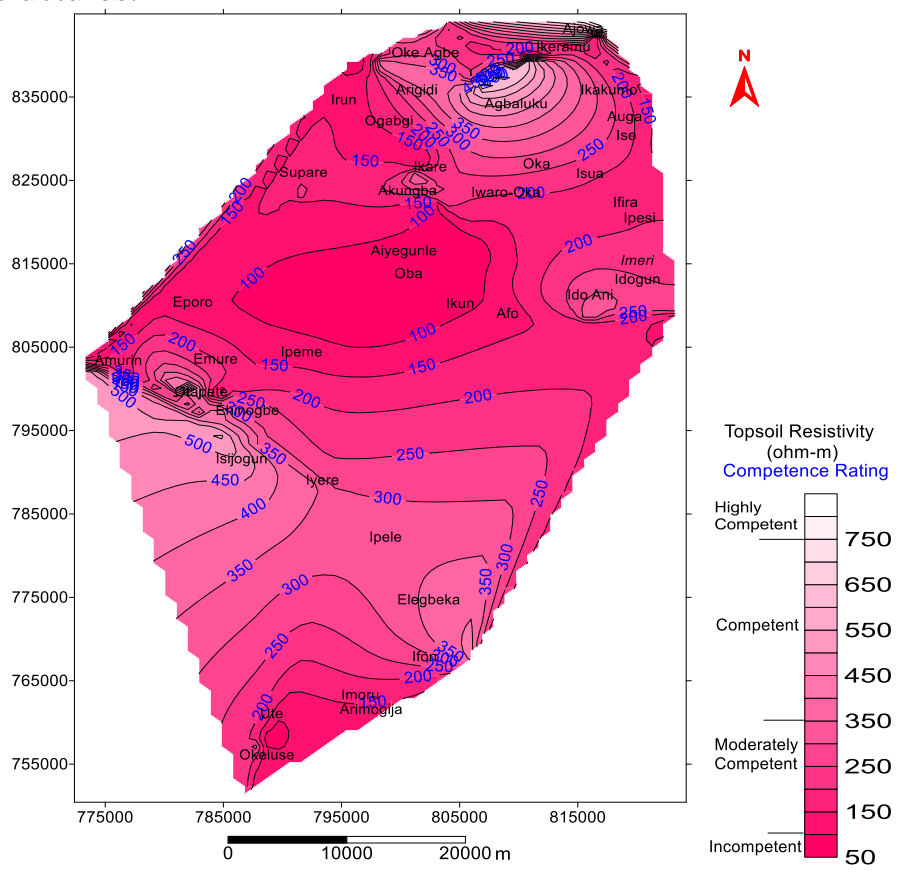

Figure 11. Map showing Topsoil Competence with prominent moderate competence

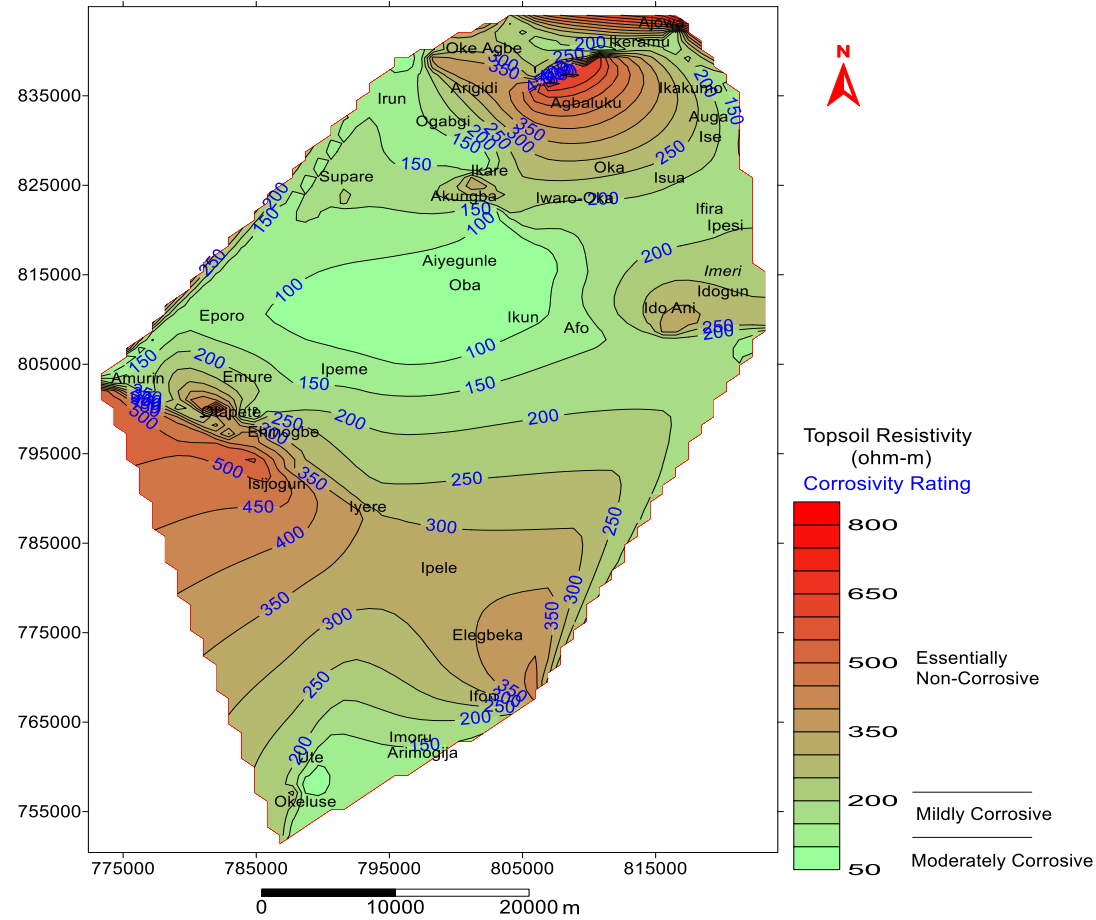

Figure 12. Map showing Topsoil Corrosivity, with pronounced mildly / Essentially non corrosivity 
Volume 2, Issue 2, 2020

ISSN: 2668-0416

Thoth Publishing House

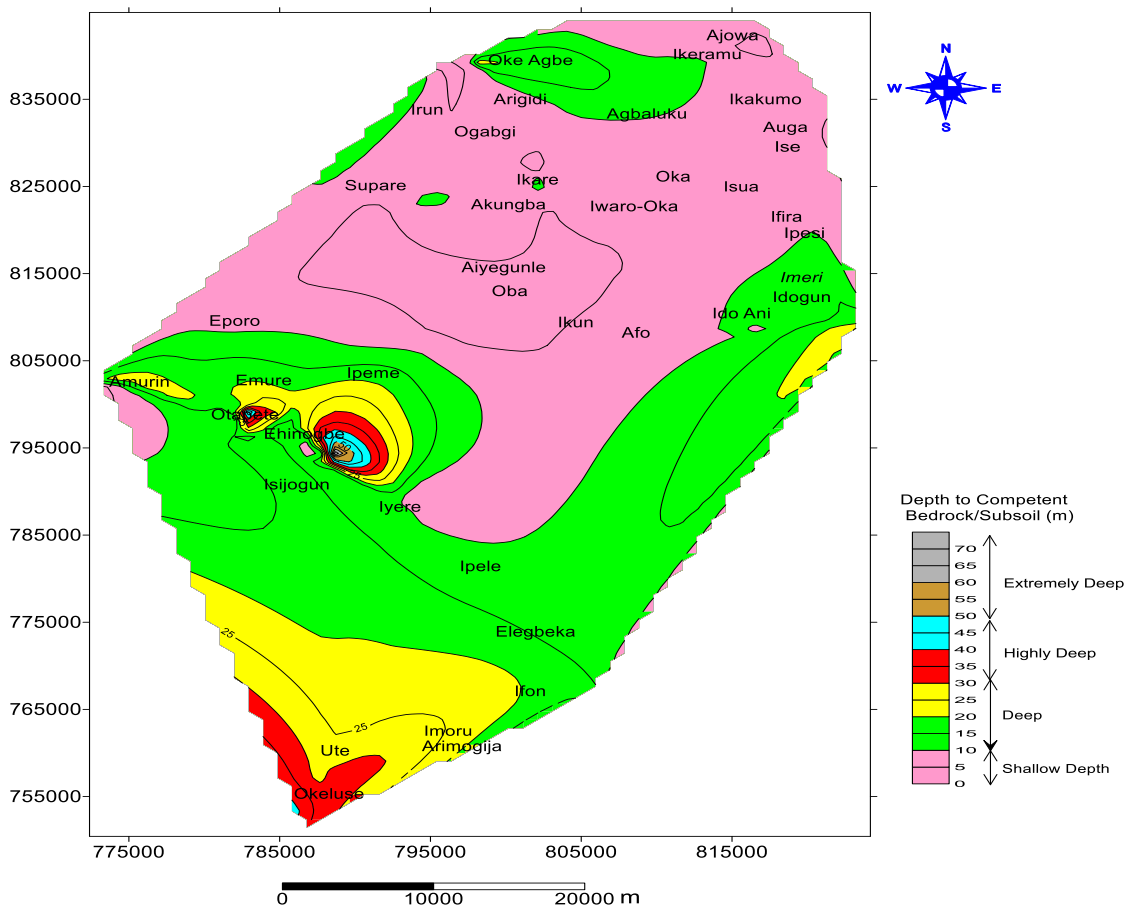

Figure 13. Map of Depth to Basement of the Study area

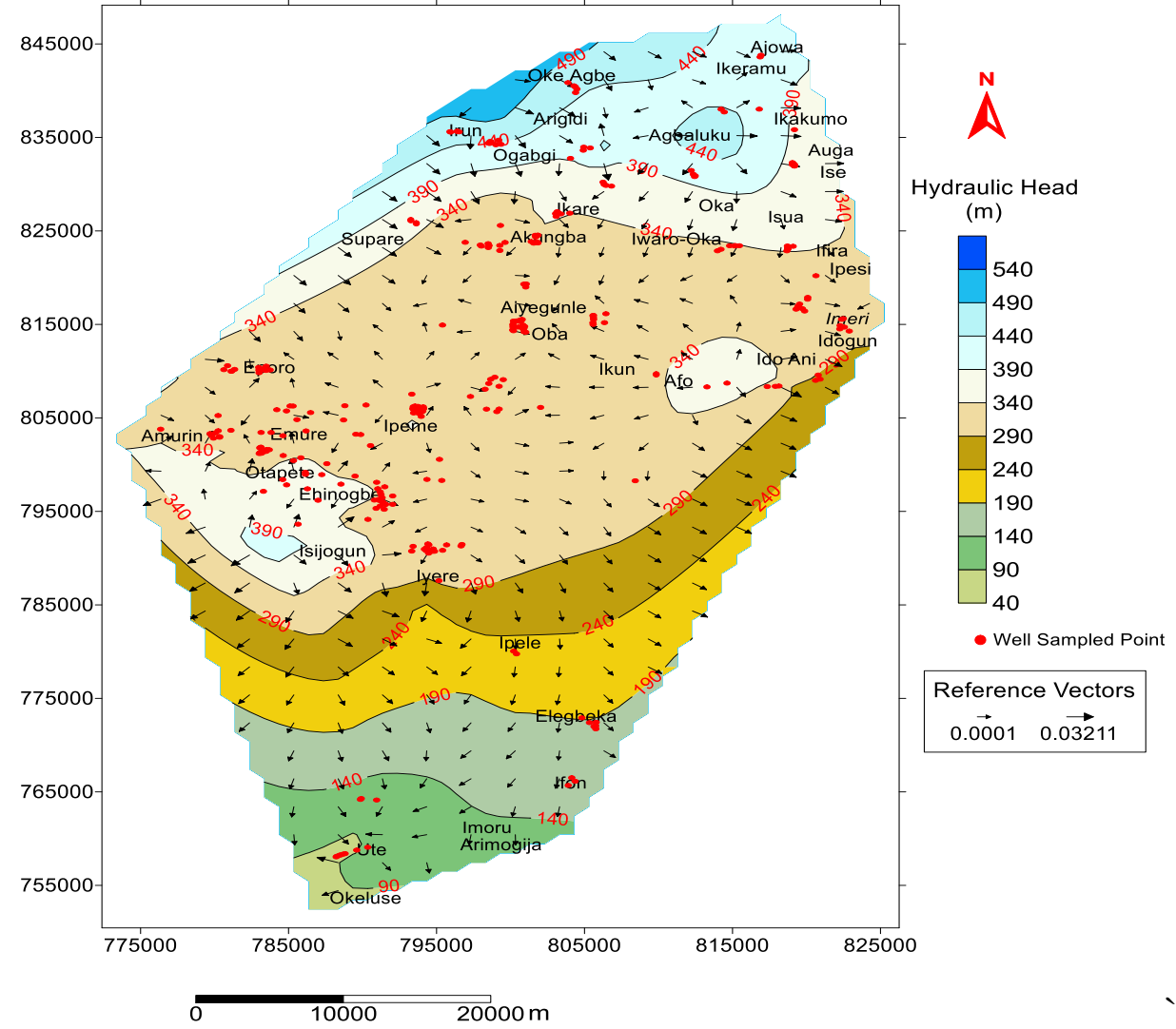

Figure 14. An overlay of Contoured Static Water Level and 1-Grid Vector Layer obtained in the Study Area with presumably North - South Flow directio 


\subsection{Geotechnical Investigation}

The summary of the geotechnical results is presented in tables 3-5. The various values of Natural Moisture Content (NMC) obtained from laboratory tests are presented in table 3. The natural moisture content gives information on the condition of the soil. The natural moisture content of soils varied from $4.3 \%$ to $17.4 \%$, with an average of $10.4 \%$. The samples have low moisture content in their natural state.

The tested soils show \% fines (percentage passing $0.002 \mathrm{~mm}$ ) variation of $14.5-54.6 \%$, with an average of $33.3 \%$. The $\%$ of sand and gravel in the sampled soils vary from $42.2 \%$ to $76 \%$ and $1.1 \%$ to $5.5 \%$ respectively. Therefore the soils are dominated by sand and clay (clayey sand) except in Ose area where the soils are dominantly clay (with classification group of sand-clay). Based on British Standard BS 1377 [13] if percentage fine is less than $35 \%$ it is adjudged a good foundation material. Therefore the soil samples can be generally classified as suitable foundation material since the mean $\%$ of fines is less than $35 \%$. However, samples taken from Ose area needs some level of stabilization due to high $\%$ of fines (clay) with high plasticity [14]. The specific gravity correlates well with the mechanical strength of sub grade and depends on the amount of sand and also on mineral constituents and mode of formation of the soil. The specific gravity (Gs) for all the soil samples and vary between $2.64-2.76$ with an average of 2.70 . These values portray resistant soil material in line with [15].

The liquid limit, plastic limit, and plasticity index of the soil samples vary from $22.2 \%$ to $54.2 \%$, $11.0 \%$ to $26.6 \%$, and $2.95 \%$ to $29.05 \%$, with average values of $39.8 \%, 23.2 \%$, and $16.2 \%$ respectively. Good foundation materials must among other significant criteria be of low plasticity such that its resistance to swelling, total expansion and linear shrinkage should be minimal. The high plasticity index and liquid limit values are indicative of poor engineering properties. The Federal Ministry of Works and Housing [16] recommended liquid limits of $50 \%$ maximum, plastic limits of $30 \%$ maximum, plasticity index of $20 \%$ maximum for civil engineering foundation/construction material. The liquid limit of the soils are generally less than $50 \%$, while the plastic limits are generally lower than $30 \%$ and the plasticity index are generally lower than $20 \%$ except samples AK 5 and 6 which are greater than $20 \%$. Hence, most of the studied soils fall within the specification. Linear shrinkage is an important parameter in the evaluation of material soils for foundation construction. It has been suggested that a linear shrinkage (LS) value below $8 \%$ is indicative of a soil that is good for foundation material $[15,17]$. The lower the linear shrinkage, the lesser the tendency of the soil to shrink when desiccated. The values range between $7.4 \%$ and $13.4 \%$ with an average value of $9.8 \%$. Using table 5 , the soils can be classified as medium good material.

The importance of compaction test is to improve the desirable load bearing capacity properties of a soil as foundation material. The best for foundation engineering structures is one with high MDD at low OMC. The OMC varies from $10.4 \%$ and $27.5 \%$ with an average of $17.1 \%$. The MDD ranges from $1532-2065 \mathrm{Kg} / \mathrm{m}^{3}$, with a mean value of $1820 \mathrm{Kg} / \mathrm{m}^{3}$. The degree of compaction is sensitive to moisture content, thus the higher the value of MDD and the lower OMC, the more suitable the material to sustain any load imposed. All the soil samples have MDD at moderately low OMC. However, MDD values are a little bit lower in Ose area with a range of $1532-1749 \mathrm{Kg} / \mathrm{m}^{3}$. Cohesion is the ability of the soil to resist shearing stress. The cohesion of the studied soils varies between 51.5 $\mathrm{kPa}-102 \mathrm{kPa}$ and average of $88.3 \mathrm{kPa}$. The values of angle of friction is between $20.4^{\circ}$ and $32.5^{\circ}$. This range of value is classified as hard soil material by Holtz and Kovacs18. The shear strength varies from $151.7 \mathrm{kPa}$ to $237.4 \mathrm{kPa}$ and average of $187 \mathrm{kPa}$. These values indicate moderately cohesive material with high shear strength.

The cone penetrometer test was carried out in order to obtain geotechnical parameters required for the design of the foundation support for civil engineering structures. From table 6, the maximum cone resistance values of $100 \mathrm{Kg} / \mathrm{cm}^{2}$ to $126 \mathrm{Kg} / \mathrm{cm}^{2}$ indicative of clayey sand and lateritic material were obtained between depths of $1.4 \mathrm{~m}$ and $3.0 \mathrm{~m}$. Six major geological layers are delineated comprising clay, clay silt, silty clay, sandy clay, clay sand, and lateritic clay. Therefore the soils show high degree of competence at Owo at depth range of $1.0-2.5 \mathrm{~m}, 1.0 \mathrm{~m}$ in Akoko area and $3.0 \mathrm{~m}$ in Ose area. 
The allowable bearing capacity of the soils in Owo, Ose and Akoko areas varies from $17 \mathrm{KN} / \mathrm{m}^{2}$ to $293 \mathrm{KN} / \mathrm{m}^{2}, 20 \mathrm{KN} / \mathrm{m}^{2}$ to $309 \mathrm{KN} / \mathrm{m}^{2}$, and $10 \mathrm{KN} / \mathrm{m}^{2}$ to $270 \mathrm{KN} / \mathrm{m}^{2}$ respectively, while the ultimate bearing capacity varies between $51 \mathrm{KN} / \mathrm{m}^{2}$ and $879 \mathrm{KN} / \mathrm{m}^{2}, 60 \mathrm{KN} / \mathrm{m}^{2}$ and $927 \mathrm{KN} / \mathrm{m}^{2}$, and $30 \mathrm{KN} / \mathrm{m}^{2}$ and $810 \mathrm{KN} / \mathrm{m}^{2}$ respectively. The settlement values obtained from the area are generally less than 20 $\mathrm{mm}$. The minimum settlement values obtained from Owo, Ose and Akoko areas ranged from $0.75 \mathrm{~mm}$ to $1.4 \mathrm{~mm}, 0.68 \mathrm{~mm}$ to $0.80 \mathrm{~mm}$, and $0.78 \mathrm{~mm}$ to $0.86 \mathrm{~mm}$ corresponding to depth(s) of $1.4 \mathrm{~m}-2.4 \mathrm{~m}$, $3 \mathrm{~m}$, and $1.4 \mathrm{~m}-2.0 \mathrm{~m}$ respectively.

Nevertheless for safety purpose Akoko area should not go beyond $1.0 \mathrm{~m}$ due to high water level. The minimum allowable bearing capacity of at least $200 \mathrm{KN} / \mathrm{m}^{2}$ (corresponding to $80-100 \mathrm{~kg} / \mathrm{cm}^{2}$ cone resistance values) for a raft, simple spread foundation and/or structure was recommended by [19]. This average value was found at depth of $1.0 \mathrm{~m}-2.4 \mathrm{~m}$ (Owo), $3.0 \mathrm{~m}$ (Ose) and $1.4 \mathrm{~m}-2.0 \mathrm{~m}$ (Akoko). These allowable bearing pressures are considered appropriate for use in the design of bases, strips or raft foundations. Subsequently, shallow foundation such as pad or raft foundation of reinforced concrete can be adopted in the study area [21]. Therefore the thematic maps of the topsoil resistivity and thickness, plasticity index, soil association, allowable bearing capacity, shear strength, lineament density, and static water level are integrated to generate a sub-soil competence map for the study area by allocating different weights/ratings to each of these parameters as shown in tables 7-9. Figure 15 shows the generated subsoil competence map of the study area. The map classifies the study area into low competence $(<40 \%)$, moderate competence $(40 \%-55 \%)$, and high competence $(55 \%$ $65 \%)$ and very high $(>65 \%)$. Low competence area are not represented on the map, while moderate competence account for $60 \%$. The high and very high competence areas account for of $35 \%$ to 5\% respectively. The very high competence occur as small closures in Ajowa, Ikeramu, Eporo, parts of Ikare, Arigidi, and Ido Ani. The moderate competence areas are prominent in parts of Owo, Ose and Akoko areas. In Owo, it's observed in Ipeme, Ipele, and Amurin. Also in Ose, it is widespread in Elegbeka, Ifon, Imoru, Arimigija, and Okeluse. In addition, moderate competence is noticed in Akoko area around Oba, Ikun, Afo, Iwao Oka, Ikakumo, Irun, Oke Agbe, Auga, and Ise. Furthermore, the high competence subsoil is observed in Owo (Eporo, Otapete, Ehinogbe, Isijogun, Iyere and Ute); and Akoko (Agbaluku, Oka, Isua, Ifira, and Ipesi).

Table 3. Summary of Results of Geotechnical Tests

\begin{tabular}{|c|c|c|c|c|c|c|c|c|c|c|c|c|c|c|}
\hline \multirow[b]{2}{*}{ LOCATION } & \multirow[b]{2}{*}{$\begin{array}{l}\text { AMPLE } \\
\text { NO. }\end{array}$} & \multirow[b]{2}{*}{$\begin{array}{c}\text { N.M.C } \\
(\%)\end{array}$} & \multicolumn{3}{|c|}{ G.S.D } & & \multicolumn{3}{|c|}{ Consistency Limits } & \multicolumn{3}{|c|}{ Compaction } & \multirow[b]{2}{*}{$\begin{array}{c}\text { AASHTO } \\
\text { Group }\end{array}$} & \multirow[b]{2}{*}{ Rating } \\
\hline & & & $\begin{array}{c}\% \\
\text { Fines }\end{array}$ & $\begin{array}{c}\% \\
\text { Sand }\end{array}$ & $\begin{array}{c}\% \\
\text { Gravel }\end{array}$ & S.G & $\begin{array}{l}\text { L.L } \\
(\%)\end{array}$ & $\begin{array}{l}\text { P.L. } \\
\text { (\%) }\end{array}$ & $\begin{array}{l}\text { P.I } \\
(\%)\end{array}$ & $\begin{array}{l}\text { L.S } \\
(\%)\end{array}$ & $\begin{array}{c}\text { OMC } \\
(\%)\end{array}$ & $\begin{array}{c}\text { MDD } \\
\left(\mathbf{K g} / \mathrm{m}^{3}\right)\end{array}$ & & \\
\hline OWO & OW 1 & 6.4 & 38.8 & 61.2 & - & 2.67 & 37.4 & 24.1 & 13.35 & 10.1 & 15.3 & 1852 & A-6 & Poor \\
\hline \multirow[t]{7}{*}{ AREA } & OW 2 & 8.3 & 43.3 & 53.5 & 3.2 & 2.69 & 39.5 & 25.2 & 14.34 & 9.6 & 16.2 & 1816 & A-6 & Poor \\
\hline & OW 3 & 4.3 & 22.7 & 76 & 1.3 & 2.66 & 22.2 & 19.3 & 2.95 & 12 & 11.9 & 1996 & A-2-4 & Good \\
\hline & OW 4 & 5.4 & 24.2 & 73.7 & 2.1 & 2.68 & 23.2 & 19.8 & 3.40 & 12 & 11.3 & 2019 & A-2-4 & Good \\
\hline & OW 5 & 6.5 & 24.1 & 74.7 & 1.2 & 2.65 & 24.0 & 19.7 & 4.35 & 12 & 10.4 & 2065 & A-2-4 & Good \\
\hline & OW 6 & 6.4 & 32.8 & 65.9 & 1.3 & 2.64 & 24.0 & 19.9 & 4.15 & 12 & 11.2 & 2035 & A-2-4 & Good \\
\hline & OW 7 & 6.5 & 38.7 & 61.3 & - & 2.65 & 31.8 & 25.2 & 6.64 & 11.5 & 18.6 & 1738 & A-5 & Fair \\
\hline & OW 8 & 7.6 & 39.0 & 59.8 & 1.2 & 2.64 & 38.4 & 26.5 & 11.95 & 10.6 & 19.5 & 1703 & A-6 & Good \\
\hline \multirow{8}{*}{ OSE AREA } & OS 1 & 6.7 & 54.3 & 44.2 & 1.5 & 2.68 & 45.0 & 23.5 & 21.50 & 8.7 & 25.9 & 1586 & A-7 & Poor \\
\hline & OS 2 & 11.3 & 54.6 & 42.2 & 3.2 & 2.68 & 52.4 & 24.3 & 28.15 & 7.7 & 27.0 & 1549 & A-7 & Poor \\
\hline & OS 3 & 11.1 & 53.3 & 45.4 & 1.3 & 2.75 & 53.4 & 24.6 & 28.85 & 7.7 & 27.5 & 1532 & A-7 & Poor \\
\hline & OS 4 & 12.4 & 52.8 & 46.1 & 1.1 & 2.76 & 54.2 & 25.2 & 29.05 & 7.7 & 26.3 & 1572 & A-7 & Poor \\
\hline & OS 5 & 11.4 & 32.6 & 66.2 & 1.2 & 2.76 & 50.4 & 26.3 & 24.10 & 7.7 & 19.0 & 1741 & A-2-6 & Good \\
\hline & OS 6 & 12.2 & 48.1 & 50.6 & 1.3 & 2.76 & 52.4 & 26.6 & 25.80 & 7.7 & 19.8 & 1711 & A-7 & Poor \\
\hline & OS 7 & 12.3 & 52.8 & 47.2 & - & 2.74 & 53.8 & 26.6 & 27.25 & 7.7 & 18.8 & 1749 & A-7 & Poor \\
\hline & OS 8 & 14.4 & 52.9 & 45.9 & 1.2 & 2.74 & 52.5 & 26.6 & 25.90 & 7.7 & 19.7 & 1715 & A-7 & Poor \\
\hline AKOKO & AK 1 & 16.4 & 16.5 & 55.6 & - & 2.72 & 37.2 & 22.4 & 14.80 & 10.1 & 14.2 & 1910 & A-2-6 & Good \\
\hline \multirow[t]{7}{*}{ AREA } & AK 2 & 12.2 & 16.1 & 64.7 & - & 2.73 & 30.0 & 22.2 & 7.85 & 12.0 & 12.1 & 1988 & A-2-4 & Good \\
\hline & AK 3 & 12.7 & 16.5 & 51.4 & 5.5 & 2.72 & 41.2 & 23.2 & 18.00 & 9.6 & 15.0 & 1879 & A-2-7 & Good \\
\hline & AK 4 & 9.3 & 14.5 & 70.9 & 2.1 & 2.73 & 27.0 & 23.3 & 3.70 & 13.4 & 11.1 & 2027 & A-2-4 & Good \\
\hline & AK 5 & 17.4 & 17.4 & 51.4 & 1.3 & 2.73 & 47.2 & 23.4 & 23.80 & 8.7 & 16.0 & 1824 & A-2-7 & Good \\
\hline & AK 6 & 16.2 & 20.9 & 49.7 & 2.2 & 2.70 & 48.4 & 23.7 & 24.75 & 8.7 & 16.5 & 1804 & A-2-7 & Good \\
\hline & AK 7 & 14.4 & 17.2 & 51.3 & 2.5 & 2.70 & 40.8 & 23.4 & 17.45 & 9.6 & 14.8 & 1885 & A-2-6 & Good \\
\hline & AK 8 & 8.2 & 15.1 & 68.7 & 3.3 & 2.69 & 27.9 & 11.0 & 6.85 & 11.0 & 11.8 & 1988 & A-2-4 & Good \\
\hline
\end{tabular}


Table 4. Results of the undrained triaxial Test

\begin{tabular}{|c|c|c|c|c|c|c|c|c|}
\hline \multirow[b]{2}{*}{ Location } & \multirow[b]{2}{*}{ Sample No. } & \multicolumn{3}{|c|}{$\begin{array}{c}(\sigma) \text { Deviator stress at } \\
\text { Different Cell Pressures } \\
(\mathrm{KPa})\end{array}$} & \multirow[t]{2}{*}{$\begin{array}{c}\text { Cohesion (c) } \\
\text { Kpa }\end{array}$} & \multirow[t]{2}{*}{$\begin{array}{l}\left(\theta^{\circ}\right) \text { Angle } \\
\text { of Friction }\end{array}$} & \multirow[t]{2}{*}{$\begin{array}{c}\text { Shear Strength } \\
(\mathbf{K P a}) \\
(\tau)\end{array}$} & \multirow{2}{*}{$\begin{array}{c}\text { Undrained } \\
\text { Compressive } \\
\text { Strength } \\
\text { @ Max. Cell } \\
\text { Pressure (Kpa) }\end{array}$} \\
\hline & & 30 & 60 & 90 & & & & \\
\hline OWO & OW 1 & 395 & 470 & 545 & 85.1 & 29.1 & 201.9 & 545 \\
\hline \multirow{7}{*}{ AREA } & OW 2 & 395 & 468 & 542 & 86.2 & 28.8 & 196.2 & 542 \\
\hline & OW 3 & 440 & 532 & 625 & 85.3 & 31.2 & 212.5 & 625 \\
\hline & OW 4 & 440 & 528 & 616 & 88.1 & 30.7 & 230.6 & 616 \\
\hline & OW 5 & 440 & 537 & 633 & 82.9 & 31.7 & 232.4 & 633 \\
\hline & OW 6 & 440 & 545 & 650 & 78.1 & 32.5 & 237.4 & 650 \\
\hline & OW 7 & 337 & 376 & 415 & 98.2 & 21.5 & 175.0 & 415 \\
\hline & OW 8 & 337 & 372 & 408 & 102.0 & 20.4 & 176.4 & 408 \\
\hline \multirow[t]{8}{*}{ OSE AREA } & OS 1 & 337 & 383 & 429 & 91.3 & 23.5 & 173.9 & 429 \\
\hline & OS 2 & 337 & 381 & 426 & 92.7 & 23.1 & 175.0 & 426 \\
\hline & OS 3 & 337 & 378 & 419 & 96.1 & 22.1 & 171.2 & 419 \\
\hline & OS 4 & 337 & 384 & 431 & 90.4 & 23.7 & 173.8 & 431 \\
\hline & OS 5 & 337 & 382 & 427 & 92.3 & 23.2 & 175.1 & 427 \\
\hline & OS 6 & 395 & 459 & 523 & 93.2 & 27.3 & 199.0 & 523 \\
\hline & OS 7 & 395 & 455 & 515 & 96.5 & 26.6 & 198.7 & 515 \\
\hline & OS 8 & 337 & 380 & 422 & 94.7 & 22.5 & 175.5 & 422 \\
\hline AKOKO & AK 1 & 337 & 380 & 422 & 94.7 & 22.5 & 173.8 & 422 \\
\hline \multirow[t]{7}{*}{ AREA } & AK 2 & 296 & 360 & 425 & 65.3 & 27.3 & 160.8 & 425 \\
\hline & AK 3 & 323 & 381 & 425 & 82.9 & 24.6 & 168.5 & 425 \\
\hline & AK 4 & 269 & 339 & 419 & 51.5 & 29.1 & 151.7 & 419 \\
\hline & AK 5 & 337 & 384 & 431 & 90.4 & 23.7 & 175.1 & 431 \\
\hline & AK 6 & 337 & 382 & 427 & 92.3 & 23.2 & 177.6 & 427 \\
\hline & AK 7 & 395 & 459 & 523 & 93.2 & 27.3 & 200.0 & 523 \\
\hline & AK 8 & 395 & 455 & 515 & 96.5 & 26.6 & 198.2 & 515 \\
\hline
\end{tabular}

Table 6. Bearing Capacity and settlements obtained for all the CPT locations at an interval of $0.2 \mathrm{~m}$ Depth

\begin{tabular}{|c|c|c|c|c|c|c|c|c|c|c|c|c|}
\hline \multirow[b]{2}{*}{$\begin{array}{l}\text { Depth } \\
(\mathrm{m})\end{array}$} & \multicolumn{3}{|c|}{ CPT 1 (OWO) } & \multicolumn{3}{|c|}{ CPT 2 (OWO) } & \multicolumn{3}{|c|}{ CPT 3 (OSE) } & \multicolumn{3}{|c|}{ CPT 4 (OSE) } \\
\hline & $\begin{array}{c}q_{a} \\
\left(\mathrm{KN} / \mathrm{m}^{2}\right)\end{array}$ & $\begin{array}{c}q_{u} \\
\left(\mathrm{KN} / \mathrm{m}^{2}\right)\end{array}$ & $\underset{(\mathrm{mm})}{\mathrm{S}}$ & $\begin{array}{c}q_{a} \\
\left(\mathrm{KN} / \mathrm{m}^{2}\right)\end{array}$ & $\begin{array}{c}q_{u} \\
\left(\mathrm{KN} / \mathrm{m}^{2}\right)\end{array}$ & $\begin{array}{c}\mathrm{S} \\
(\mathrm{mm})\end{array}$ & $\begin{array}{c}q_{a} \\
\left(\mathrm{KN} / \mathrm{m}^{2}\right)\end{array}$ & $\begin{array}{c}q_{u} \\
\left(\mathrm{KN} / \mathrm{m}^{2}\right)\end{array}$ & $\underset{(\mathrm{mm})}{\mathrm{S}}$ & $\begin{array}{c}q_{a} \\
\left(\mathrm{KN} / \mathrm{m}^{2}\right)\end{array}$ & $\begin{array}{c}q_{u} \\
\left(\mathrm{KN} / \mathrm{m}^{2}\right)\end{array}$ & $\underset{(\mathrm{mm})}{\mathrm{S}}$ \\
\hline 0.2 & 17 & 51 & 12.3 & 41 & 123 & 5.1 & 21 & 63 & 10.25 & 22 & 66 & 9.67 \\
\hline 0.4 & 21 & 63 & 10.01 & 82 & 246 & 2.56 & 20 & 60 & 10.37 & 31 & 93 & 6.78 \\
\hline 0.6 & 54 & 162 & 3.91 & 127 & 381 & 1.67 & 26 & 78 & 8.05 & 43 & 129 & 4.86 \\
\hline 0.8 & 63 & 189 & 3.32 & 174 & 522 & 1.22 & 32 & 96 & 6.67 & 42 & 126 & 5.01 \\
\hline 1.0 & 87 & 261 & 2.41 & 270 & 810 & 0.78 & 43 & 129 & 4.89 & 76 & 228 & 2.79 \\
\hline 1.2 & 102 & 306 & 2.07 & 273 & 819 & 0.77 & 70 & 210 & 2.99 & 10 & 30 & 21.00 \\
\hline 1.4 & 112 & 336 & 1.88 & 293 & 879 & 0.72 & 88 & 264 & 2.41 & 11 & 33 & 19.13 \\
\hline 1.6 & 124 & 369 & 1.71 & - & - & - & 83 & 249 & 2.55 & 21 & 63 & 10.13 \\
\hline 1.8 & 123 & 369 & 1.72 & - & - & - & 98 & 294 & 2.16 & 33 & 98 & 6.47 \\
\hline 2.0 & 131 & 393 & 1.62 & - & - & - & 116 & 348 & 1.82 & 42 & 126 & 5.01 \\
\hline 2.2 & 179 & 537 & 1.18 & - & - & - & 123 & 369 & 1.72 & 61 & 183 & 3.44 \\
\hline 2.4 & 281 & 843 & 0.75 & - & - & - & 156 & 468 & 1.35 & 83 & 249 & 2.54 \\
\hline 2.6 & - & - & - & - & - & - & 172 & 516 & 1.23 & 112 & 336 & 1.88 \\
\hline 2.8 & - & - & - & - & - & - & 215 & 645 & 0.98 & 163 & 489 & 1.29 \\
\hline \multirow[t]{2}{*}{3.0} & - & - & - & - & - & - & 309 & 927 & 0.68 & 262 & 786 & 0.80 \\
\hline & \multicolumn{3}{|c|}{ CPT 5 (AKOKO) } & \multicolumn{3}{|c|}{ CPT 6 (AKOKO) } & \multicolumn{3}{|c|}{ CPT 7 (AKOKO) } & \multicolumn{3}{|c|}{ CPT $8($ AKOKO) } \\
\hline $\begin{array}{l}\text { Depth } \\
\text { (m) }\end{array}$ & $\begin{array}{c}q_{a} \\
\left(\mathrm{KN} / \mathrm{m}^{2}\right)\end{array}$ & $\begin{array}{c}q_{u} \\
\left(\mathrm{KN} / \mathrm{m}^{2}\right)\end{array}$ & $\underset{(\mathrm{mm})}{\mathrm{S}}$ & $\begin{array}{c}q_{a} \\
\left(\mathrm{KN} / \mathrm{m}^{2}\right)\end{array}$ & $\begin{array}{c}q_{u} \\
\left(\mathrm{KN} / \mathrm{m}^{2}\right)\end{array}$ & $\underset{(\mathrm{mm})}{\mathrm{S}}$ & $\begin{array}{c}q_{a} \\
\left(\mathrm{KN} / \mathrm{m}^{2}\right)\end{array}$ & $\begin{array}{c}q_{u} \\
\left(\mathrm{KN} / \mathrm{m}^{2}\right)\end{array}$ & $\underset{(\mathrm{mm})}{\mathrm{S}}$ & $\begin{array}{c}q_{a} \\
\left(\mathrm{KN} / \mathrm{m}^{2}\right)\end{array}$ & $\begin{array}{c}q_{u} \\
\left(\mathrm{KN} / \mathrm{m}^{2}\right)\end{array}$ & $\underset{(\mathrm{mm})}{\mathrm{S}}$ \\
\hline 0.2 & 22 & 66 & 9.78 & 10 & 30 & 21.00 & 61 & 183 & 3.44 & 11 & 33 & 19.57 \\
\hline 0.4 & 20 & 60 & 10.50 & 22 & 66 & 9.67 & 39 & 117 & 5.38 & 25 & 75 & 8.36 \\
\hline 0.6 & 33 & 99 & 6.43 & 52 & 156 & 4.06 & 21 & 63 & 10.01 & 54 & 162 & 3.90 \\
\hline 0.8 & 43 & 129 & 4.86 & 82 & 246 & 2.59 & 54 & 162 & 3.90 & 121 & 363 & 1.75 \\
\hline 1.0 & 53 & 159 & 3.99 & 163 & 489 & 1.29 & 125 & 375 & 1.69 & 162 & 486 & 1.30 \\
\hline 1.2 & 73 & 219 & 2.91 & 195 & 585 & 1.08 & 153 & 459 & 1.38 & 207 & 621 & 1.02 \\
\hline 1.4 & 82 & 246 & 2.59 & 249 & 747 & 0.85 & 197 & 591 & 1.07 & 248 & 744 & 0.85 \\
\hline 1.6 & 109 & 327 & 1.94 & - & - & - & 245 & 735 & 0.86 & - & - & - \\
\hline 1.8 & 173 & 519 & 1.22 & - & - & - & - & - & - & - & - & - \\
\hline 2.0 & 270 & 810 & 0.78 & - & - & - & - & - & - & - & - & - \\
\hline
\end{tabular}


Table 7. Rating of Subsoil Competence using Resistivity values [22]

\begin{tabular}{ccc}
\hline $\begin{array}{c}\text { Apparent Resistivity Range } \\
(\text { ohm-m) }\end{array}$ & Lithology & Competence Rating \\
\hline$<100$ & Clay & Incompetent \\
$100-350$ & Sandy clay & Moderately competent \\
$350-750$ & Clayey sand & Competent \\
$>750$ & Sand/Laterite/Crystalline Rock & Highly competent \\
\hline
\end{tabular}

Table 8. Soil Corrosivity Rating [23]

Soil Resistivity (ohm-m)

\section{$>250$}

$150-250$

$50-150$

UP to 50
Corrosivity Rating Essentially/Practically Non-corrosive Mildly/Slightly Corrosive

Moderately Corrosive

Very Strongly Corrosive

Table 9. Multi-criteria Evaluation Parameters for the Subsoil Competence Map

\begin{tabular}{|c|c|c|c|c|}
\hline $\mathbf{S} / \mathbf{N}$ & Thematic Map & Attribute & Rating (\%) & Weight-Age (\%) \\
\hline & Topsoil Resistivity (ohm-m) & $<100$ & 1 & \\
\hline \multirow[t]{3}{*}{1} & & $100-350$ & 5 & 15 \\
\hline & & $350-750$ & 10 & \\
\hline & & $>750$ & 15 & \\
\hline & Topsoil Thickness (m) & $<5$ & 3 & \\
\hline \multirow[t]{2}{*}{2} & & $5-10$ & 10 & 15 \\
\hline & & $>10$ & 15 & \\
\hline \multirow{3}{*}{3} & Plasticity Index (\%) & $<10$ & 10 & \\
\hline & & $10-20$ & 5 & 10 \\
\hline & & $>20$ & 1 & \\
\hline \multirow{3}{*}{4} & Shear Strength (KPa) & $200-300$ & 5 & \\
\hline & & $300-400$ & 10 & 15 \\
\hline & & $400-500$ & 15 & \\
\hline \multirow{4}{*}{5} & Allowable Bearing Capacity & $<50$ & 1 & \\
\hline & $\left(\mathrm{KN} / \mathrm{m}^{2}\right)$ & $50-100$ & 5 & 15 \\
\hline & & $100-200$ & 10 & \\
\hline & & $>200$ & 15 & \\
\hline \multirow{3}{*}{6} & Soil Association & Okemesi & 10 & 10 \\
\hline & & Iwo & 7 & \\
\hline & & Ondo & 3 & \\
\hline \multirow{3}{*}{7} & Lineament Density & $0-8$ & 10 & 10 \\
\hline & & $8-12$ & 6 & \\
\hline & & $12-16$ & 2 & \\
\hline \multirow{3}{*}{8} & Groundwater Level & $<3 \mathrm{~m}$ & 2 & 10 \\
\hline & & $3-5 \mathrm{~m}$ & 5 & \\
\hline & & $>5 \mathrm{~m}$ & 10 & \\
\hline
\end{tabular}

\section{Conclusion}

The engineering competence of the subsoil/rock in selected northern area of Ondo State was conducted, and the results of various parameters measured were integrated to generate an engineering competence map for the study area. The research work was able to meet up with its set objectives except that it has not been able to (fully) determine the geotechnical capability of the rock units in the study area to host engineering structures such as building, road, dam etc. The generated subsoil 
competence map classified the study area into low competence $(<40 \%)$, moderate competence $(40 \%$ $55 \%)$, and high competence $(55 \%-65 \%)$ and very high $(>65 \%)$.

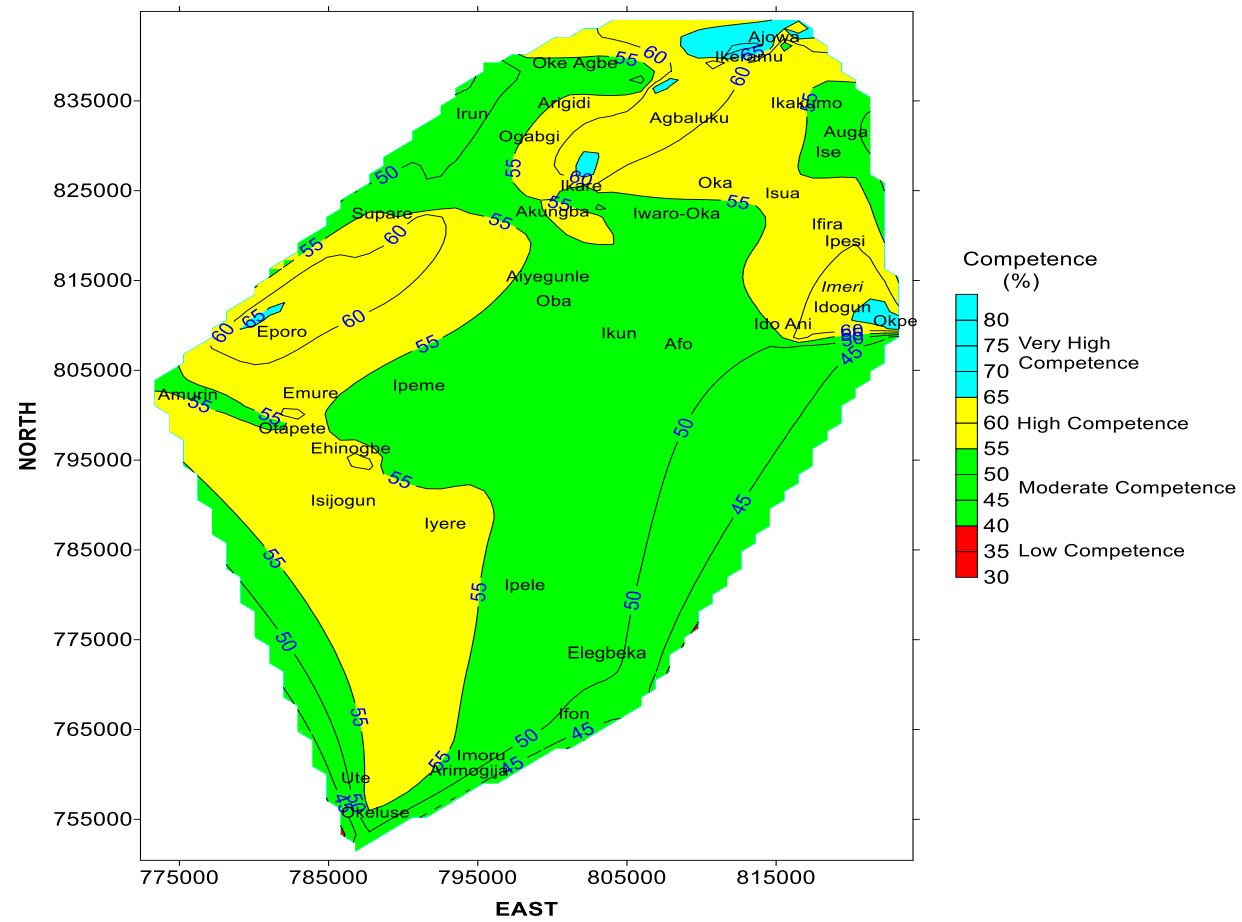

Figure 15. Subsoil Competence Map generated for the Study Area

Low competence area are not represented on the map, while moderate competence account for $60 \%$. The high and very high competence areas shared the remaining $40 \%$ in a proportion of $35 \%$ to $5 \%$. The corrosivity map of the topsoil shows predominant moderate to mildly corrosivity, prominently in Ose and Akoko areas, and constitute about $70 \%$. The essentially non-corrosive areas of the topsoil account for $10 \%$. The corrosivity of the weathered layer (subsoil) generally varies from mildly corrosivity to essentially non-corrosivity. This type of corrosivity is suitable for buried communication equipment and electrodes, as it will protect the instrumentation when there is lighting or thunderstorm; hence any protected steel or metal structure buried within the area may not be "seriously" affected by chemical corrosion

\section{References}

[1] Oyedele K F, Oladele S and Adedoyin O 2011 Application of Geophysical and Geotechnical Methods to Site Characterization for Construction Purposes at Ikoyi, Lagos, Nigeria Journal of Earth Sciences and Geotechnical Engineering vol. 1 (1) pp 87-100. ISSN: 1792-9040 (print), 1792-9660 (online) International Scientific Press.

[2] Olorunfemi M O, J S Ojo F A, Sonuga, O A and Oladapo M I 2000 Geoelectric and electromagnetic Investigations of failed Koza and Nassarawa Earth dams around Katsina, Northern Nigeria Journal of Mining and Geology 36(1) pp $51-65$.

[3] Ofomola M O, Adiat K A N, Olayanju G M and Ako B D 2009. Integrated geophysical methods for post foundation studies, Obanla Staff Quarters of the Federal University of Technology, Akure Nigeria The Pacific Journal of Science and Technology 10(2), pp 93 - 110.

[4] Marans R W and Rodgers W 1975 Toward an understanding of community satisfaction: In 
Hawley A.H. and Rock V.P. (Eds). Metropolitan America in Contemporary Perspective, London: Wiley Publishing.

[5] Federal Meteorological Survey 1982 Atlas of the Federal Republic of Nigeria, Second Edition. Federal Surveys, Lagos, Nigeria 160pp.

[6] Dada S S $1999 \mathrm{~Pb}-\mathrm{Pb}$ and Sm-Nd Isotope Study of Metaigneous Rocks of Kaduna Region: implications for Archaean Crustal Development in Northern Nigeria Global J. Pure Appl. Sci. (6) $7 \mathrm{pp}$

[7] Rahaman M A 1988 Review of the basement Geology of Southwestern Nigeria. In Kogbe (Ed): Geology of Nigeria. Rocks view (Nig) Ltd, Jos. Nigeria. pp. 39-56.

[8] Smith A J and Montgomery R F 1962 Soils and land use in Central Western Nigeria. The Government of Western Nigeria, Ibadan Publication.

[9] Daramola J O, Adekunle M F, Olaniyi M O and Alayaki F M 2009 Diagnostic Survey Report of Ondo State Agricultural Production, Institute of Food Security, Environmental Resources and Agricultural Research, University of Agriculture, Abeokuta, Nigeria pp. 171. Available www.unaab.edu.ng/ifserar

[10] Geological Survey of Nigeria 1984 Geological Map of Southwestern Nigeria. Geological Survey Department, Ministry of Mines, Power and Steel, Nigeria.

[11] Edet A E, Okereke C S, Teme S C and Esu E O 1998 Application of remote sensing data to groundwater exploration: a case study of Cross River State, Southeastern Nigeria Hydrogeology Journal 6(3) pp 394-404. http://dx.doi.org/1010.1007/s100400050162

[12] Olorunfemi M O 2008 Voyage on the Skin of the Earth: A Geophysical Experience. Inaugural Lecture 211 Obafemi Awolowo University, Ile-Ife 75 pp.

[13] British Standard Institution 1990 Methods of Test for Soil for Civil Engineering Purposes. BS1377, London.

[14] Okogbue C O and T U S Onyeobi 1999 Potential of marble dust to stabilize red tropical soils for road Construction. Engineering Geology 53 pp. $371-380$.

[15] Brink A B A, Parridge J C and Williams A A B 1992 Soil Survey for Engineering, Claredon, Oxford.

[16] Federal Ministry of Works and Housing 1972 Highway Manual Part 1, Road and Bridge Design, Federal Ministry of Works and Housing, Lagos.

[17] Madedor A C 1983 Pavement design guidelines and practice for different geological area in Nigeria. In: Ola S.A. (Ed) tropical soil of Nigeria in engineering practice. A.A. Balkema, Rotterdam, pp. 291-297.

[18] Holtz W G and Kovacs W D 1981 An Introduction to Geotechnical Engineering, Prentice-Hall Publishers, New Jersey 733pp.

[19] Bell F G 2007 Engineering geology, second edition, Elsevier Ltd 581pp.

[20] Murthy V N S 2007 Advanced Foundation Engineering, Geotechnical Engineering Series. CBS Publishers and Distributors Ltd., New Delhi - 110002, India 795pp.

[21] Schmertmann J H 1978 Guidelines for Cone Penetration Test: Performance and Design. US Department of Transportation, Washington, DC.

[22] Idornigie A I, Olorunfemi M O and Omitogun A A 2006 Integration of remotely sensed and geophysical data sets in engineering site characterization in a Basement complex of southwestern Nigeria. Journal of Applied Sciences Research, 2(9) pp. 541-552.

[23] Agunloye O 1984 Soil aggressivity along steel pipeline route at Ajaokuta, J. Mining Geol. 21(1 \& 2): pp. 97-101.

\section{Acknowledgments}

Special thanks go to Mr. Samuel Alabi of Engineering geology Laboratory, Federal University of Technology Akure, Ondo State Nigeria. 